Bond University

Research Repository

\title{
Combining Efficiency and Innovation to Enhance Performance: Evidence from Firms in Emerging Economies
}

Tian, Xiaowen; Lo, Vai Io; Zhai, Xiaoxuan

Published in:

Journal of Management and Organization

DOI:

10.1017/jmo.2018.75

Licence:

Other

Link to output in Bond University research repository.

Recommended citation $(A P A)$ :

Tian, X., Lo, V. I., \& Zhai, X. (2021). Combining Efficiency and Innovation to Enhance Performance: Evidence from Firms in Emerging Economies. Journal of Management and Organization, 27(2), 295-311.

https://doi.org/10.1017/jmo.2018.75

\section{General rights}

Copyright and moral rights for the publications made accessible in the public portal are retained by the authors and/or other copyright owners and it is a condition of accessing publications that users recognise and abide by the legal requirements associated with these rights.

For more information, or if you believe that this document breaches copyright, please contact the Bond University research repository coordinator. 


\section{Cambridge Core Share}

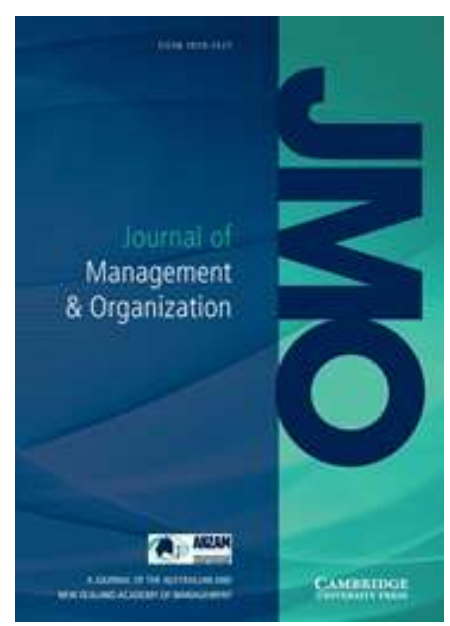

Combining efficiency and innovation to enhance performance: Evidence from firms in emerging economies

Journal of Management \& Organization, Volume 27, Issue 2

XIAOWEN TIAN, VAI IO LO, XIAOXUAN ZHAI

DOI: $10.1017 / j m o .2018 .75$

Published online: 19 December 2018, pp. 295-311

Print publication: March 2021

\section{Read this article for free}

\section{Abstract}

This paper extends the resource-capability-based view in strategic management and discusses the capabilities for the firms to stay competitive in emerging economies. Faced with low levels of efficiency, technology, and skills, firms in emerging economies need to implement best management practices to overcome operational inefficiency while engage in innovation processes to address new opportunities. They have to develop the capabilities to enhance efficiency, the capabilities to undertake innovation, and the synthesis capabilities to combine the two to keep rivals at bay. The paper tests hypotheses against a data set of more than 20,000 firms from 36 emerging economies provided by the World Bank in 2012-2015 and finds strong evidence to support the arguments. The paper finds that the three sets of capabilities are positively related to productivity and, through it, financial performance.

\section{How does Cambridge Core Share work?}

Cambridge Core Share allows authors, readers and institutional subscribers to generate a URL for an online version of a journal article. Anyone who clicks on this link will be able to view a read-only, up-to-date copy of the published journal article. 